\title{
Surface location of HPr, a phosphocarrier of the phosphoenolpyruvate:sugar phosphotransferase system in Streptococcus suis
}

\author{
J. D. Dubreuil,, ${ }^{1}$ M. Jacques, ${ }^{1}$ D. Brochu, ${ }^{2}$ M. Frenette ${ }^{2}$ \\ and C. Vadeboncoeur ${ }^{2}$ \\ Author for correspondence: C. Vadeboncoeur. Tel: +1 418656 2319. Fax: +1 4186562861. \\ e-mail: Christian.Vadeboncoeur@greb.ulaval.ca
}

\footnotetext{
1 Department of Pathology and Microbiology, Faculty of Veterinary Medicine, Université de Montréal, PO Box 5000, Saint Hyacinthe, Québec, Canada J2S 7C6

2 Groupe de Recherche en Ecologie Buccale (GREB), Department of Biochemistry (Sciences) and Faculty of Dentistry, Université Laval, Québec, Canada G1K 7P4
}

\begin{abstract}
HPr is a low-molecular-mass phosphocarrier protein of the bacterial phosphoenolpyruvate (PEP): sugar phosphotransferase system (PTS) found in the cytoplasm or associated with the inner surface of the cytoplasmic membrane. Treatment of Streptococcus suis cells with a Sorvall Omnimixer, a technique used to extract cell surface components, resulted in the extraction of a major protein with a molecular mass of $9 \mathbf{~ k D a}$. Several lines of evidence suggested that this protein was HPr: (i) the S. suis protein showed homology over the first $35 \mathrm{~N}$-terminal amino acid residues with the HPrs of Streptococcus salivarius and Streptococcus mutans, including the signature sequence for the site of PEP-dependent phosphorylation; (ii) it cross-reacted with the $S$. salivarius anti-HPr antibody preparation; (iii) it could be phosphorylated by enzyme $I$ at the expense of PEP, and by a membrane-associated kinase at the expense of ATP; and (iv) it possessed phosphocarrier activity when used as a source of HPr in an in vitro PTS assay. The data suggested that a portion of the cellular HPr is associated with the external cell surface in $S$. suis, a result that was confirmed by immunogold electron microscopy. The cellular HPr of S. suis consisted of two forms that could be distinguished by the presence or the absence of the $\mathbf{N}$-terminal methionine. Amino acid sequence analysis indicated that the cell-surface-associated HPr of S. suis lacked the $\mathbf{N}$-terminal methionine residue.
\end{abstract}

Keywords: $\mathrm{HPr}$, phosphotransferase system, cell surface proteins, Streptococcus suis, methionine aminopeptidase

\section{INTRODUCTION}

Streptococci use mainly sugars as energy sources and, in many instances, transport them by the phosphoenolpyruvate:sugar phosphotransferase system (PTS) (Hamilton, 1987; Thompson, 1987). This transport system concomitantly catalyses the transport and the phosphorylation of several mono- and disaccharides at the expense of phosphoenolpyruvate (PEP) (Meadow et al., 1990; Postma et al., 1993). The PTS is composed of several soluble and membrane-associated proteins, and

Abbreviations: El, enzyme I; Ell or II, enzyme II; PEP, phosphoenolpyruvate; PTS, phosphoenolpyruvate:sugar phosphotransferase system.

The $\mathrm{N}$-terminal amino acid sequence of $\mathrm{S}$. suis $\mathrm{HPr}$ will appear in the PIR database under the accession number A57222. transfers the phosphate group from PEP to the incoming sugar in an orderly sequence (Meadow et al., 1990; Postma et al., 1993). The first step of this energyconserving cascade is catalysed by Enzyme I (EI), which phosphorylates a small protein, designated $\mathrm{HPr}$, on a histidine residue at position 15 at the expense of PEP. Thereafter, $\mathrm{HPr}(\mathrm{His} \sim \mathrm{P})$ transfers its phosphate group to a family of multi-domain protein complexes designated Enzyme IIs (EII) that catalyse the transport and phosphorylation of sugars (Saier \& Reizer, 1992).

Several results suggest that HPr possesses other physiological functions besides its role as a phosphocarrier in sugar transport. The HPrs of several Gram-positive bacteria and mycoplasmas, including species that do not possess an active PTS, can be reversibly phosphorylated on a serine residue at position 46 by an ATP-dependent 
protein kinase and a $\mathrm{P}_{\mathrm{i}}$-dependent $\mathrm{HPr}(\mathrm{Ser}-\mathrm{P})$ phosphatase (Deutscher et al., 1989; Postma et al., 1993; Reizer et al., 1989, 1993b). The various regulatory roles that have been assigned to $\mathrm{HPr}(\mathrm{Ser}-\mathrm{P})$ were recently reviewed (Vadeboncoeur, 1995).

In streptococci and lactococci, HPrs are subjected to further chemical modification consisting of a partial cleavage of the $\mathrm{N}$-terminal methionine (Met), giving rise to two forms of $\mathrm{HPr}$ that are designated HPr-1 (without Met) and HPr-2 (with Met) (Robitaille et al., 1991; Vadeboncoeur $e t$ al., 1991b). These two forms of HPr can be phosphorylated at the expense of PEP by the EI of the PTS and by the HPr-specific ATP-dependent kinase. The physiological relevance of the partial removal of the $\mathrm{N}$ terminal Met in $\mathrm{HPr}$ is unclear, but the $\mathrm{HPr}-1 / \mathrm{HPr}-2$ ratio varies in Streptococcus salivarius according to growth conditions (Robitaille et al., 1991; Vadeboncoeur $e t$ al., 1993). Circumstantial evidence is, however, accumulating that streptococcal HPrs lacking the $\mathrm{N}$-terminal Met may be surface-located: (1) using an extraction method that did not disrupt cells, Jenkinson (1989) isolated the Streptococcus sanguis $\mathrm{HPr}$ and showed by sequence analysis that the purified protein lacked the N-terminal Met; (2) a low-molecular-mass protein lacking the $\mathrm{N}$-terminal Met, and possessing $100 \%$ identity with the $19 \mathrm{~N}$-terminal amino acids of the $S$. salivarius $\mathrm{HPr}$, was purified from a Streptococcus pyogenes culture supernatant (Gerlach et al., 1992); (3) Sutcliffe et al. (1993) identified the Streptococcus mutans surface antigen $\mathrm{D}$ as an $\mathrm{HPr}$, and demonstrated that it lacked the N-terminal Met, whereas its cytosolic counterpart was a mixture of $\mathrm{HPr}-1$ and $\mathrm{HPr}-2$.

Streptococcus suis is associated with different swine (Higgins et al., 1990), ruminant (Hommez et al., 1986) and human (Arends \& Zanen, 1988; Trottier et al., 1991) pathologies. Results presented here demonstrate that this bacterial species possesses the two forms of $\mathrm{HPr}$, designated $\mathrm{HPr}$ 1 and $\mathrm{HPr}-2$, and provide for the first time convincing direct evidence that a portion of the cellular HPr-1 is located at the cell surface.

\section{METHODS}

Bacterial strains and growth conditions. S. suis strain $170 \mathrm{~B}$, isolated from swine lungs and belonging to serotype 19, was obtained from Dr R. Higgins (Clinical Diagnostic Laboratory, Faculty of Veterinary Medicine, St Hyacinthe, Québec, Canada). S. salivarius ATCC 25975 was kindly provided by Dr I. R. Hamilton (University of Manitoba, Canada). S. suis was grown in Todd-Hewitt broth for $18 \mathrm{~h}$ at $37^{\circ} \mathrm{C}$ with agitation (200 r.p.m.). S. salivarius was grown at $37^{\circ} \mathrm{C}$ without agitation in TYE medium containing $17 \mathrm{~g}$ Trypticase (BBL Microbiclogy Systems), $3 \mathrm{~g}$ yeast extract (Difco), $5 \mathrm{~g} \mathrm{NaCl}, 2.5 \mathrm{~g}$ disodium phosphate and $50 \mathrm{~g}$ glucose or fructose per litre.

Extraction of surface components. A $350 \mathrm{ml}$ culture of $S$. suis was grown as described above, harvested by centrifugation at $10000 \mathrm{~g}$ for $30 \mathrm{~min}$ and resuspended in $0.01 \mathrm{M}$ sodium phosphate $(\mathrm{pH} \mathrm{7.2)}$ containing $1 \mathrm{mM}$ PMSF. Cells received two 5 min treatments on ice in a model 17105 Sorval Omni-mixer (Dupont Instruments) at 15000 r.p.m., a technique used to isolate bacterial surface appendages (Heckels \& Virji, 1988). After centrifugation of the blended preparation $(10000 \mathrm{~g}$ for
$30 \mathrm{~min}$ ), urea was added to the supernatant to a final concentration of $6 \mathrm{M}$. The solution was kept at $4{ }^{\circ} \mathrm{C}$ for $60 \mathrm{~min}$ and then centrifuged at $25000 \mathrm{~g}$ for $90 \mathrm{~min}$. The supernatant was filtered through a $0.22 \mu \mathrm{m}$ Millipore membrane, dialysed against distilled water and concentrated using an Amicon ultrafiltration unit fitted with a YM 30 membrane.

Amino acid sequence analysis. Automated Edman degradation was performed in a gas-phase sequencer (model 470A) equipped with an on-line phenylthiohydantoin analyser (model 120A) from Applied Biosystems using the general protocol of Hewick et al. (1980). The sample was applied to a trifluoroacetic-acidtreated cartridge filter coated with $1.5 \mathrm{mg}$ polybrene and $0.1 \mathrm{mg}$ $\mathrm{NaCl}$ (Biobrene Plus, ABI). A standard program (03RPTH, $\mathrm{ABI}$ ) was used for sequencing. The phenylthiohydantoin amino acid derivatives were identified by comparison with standards (PTH Analyser standards, ABI) analysed on-line prior to sequence analysis. Sequence comparison was carried out using the GCG sequence analysis software package (Devereux et al., 1984).

Electrophoretic procedures. PAGE in the presence of SDS and urea was carried out as described by Swank \& Munkres (1971), and proteins were stained with Coomassie blue. The separation of HPr-1 and HPr-2 by non-denaturing electrophoresis was carried out as described previously (Robitaille et al., 1991). For Western blotting, proteins were transferred electrophoretically at $4 \mathrm{~V} \mathrm{~cm}^{-1}$ overnight to a nitrocellulose membrane $(0.45 \mu \mathrm{m}$ pore size) according to Towbin et al. (1979). Following transfer, the membrane was treated for 60 min with $2 \%$ casein in $10 \mathrm{mM}$ Tris $/ \mathrm{HCl}(\mathrm{pH} \mathrm{8.0)}$ containing $150 \mathrm{mM} \mathrm{NaCl}$ to block unoccupied sites, and then incubated with rabbit anti-S. salivarius $\mathrm{HPr}$ antiserum for $90 \mathrm{~min}$ at room temperature. The membrane was then washed three times with $10 \mathrm{mM}$ Tris $/ \mathrm{HCl}(\mathrm{pH} 8.0)$ containing $150 \mathrm{mM} \mathrm{NaCl}$, incubated with peroxidaseconjugated anti-rabbit immunoglobulin $G$ for $60 \mathrm{~min}$, and developed with $10 \mathrm{ml} \mathrm{0.3 \%} \mathrm{4-chloro-1-naphthol} \mathrm{(Sigma)} \mathrm{in}$ cold methanol mixed with $50 \mathrm{ml} 0.06 \% \mathrm{H}_{2} \mathrm{O}_{2}$ in Tris-saline (10 mM Tris $/ \mathrm{HCl}, 0.9 \% \mathrm{NaCl}, \mathrm{pH} 7.4$ ) (Hawkes, 1982). Crossed immunoelectrophoresis was conducted as described by Vadeboncoeur et al. (1991a). Antiserum against $\mathrm{HPr}$ was obtained from female New Zealand White rabbits after immunization by multisite subcutaneous injection (Gauthier et al., 1984). Approximately $200 \mu \mathrm{g}$ protein was injected for both the primary and booster injections.

PTS assay. S. salivarius 25975 was grown in the presence of $0.5 \%$ fructose and harvested at mid-exponential phase. Membrane fragments containing the PTS EII complexes were prepared as previously described (Hamilton et al., 1989). The PTS-dependent phosphorylation of fructose was carried out in a reaction medium $(600 \mu \mathrm{l})$ containing $50 \mathrm{mM}$ sodium phosphate (pH 7.0), $4 \mathrm{mM} \mathrm{MgCl}$, 2 mM PEP, 5 mM 2-mercaptoethanol, $10 \mathrm{mM} \mathrm{NaF}, 10 \mathrm{mM}\left[{ }^{14} \mathrm{C}\right]$ fructose $\left[0.1 \mathrm{mCi} \mathrm{mmol}^{-1}(37.5 \mathrm{kBq}\right.$ $\left.\mathrm{mmol}^{-1}\right)$ ], $1.5 \mu \mathrm{g}$ purified $S$. sanguis EI, $16.5 \mu \mathrm{g}$ purified $\mathrm{HPr}$ from $S$. salivarius or $15 \mu \mathrm{g}$ of the $9 \mathrm{kDa}$ protein extracted from $S$. suis and $20 \mu \mathrm{g} S$. salivarius membrane proteins as a source of EII complexes. After a pre-incubation of $10 \mathrm{~min}$ at $37^{\circ} \mathrm{C}$, the labelled sugar was added, and the reaction was allowed to continue for $1 \mathrm{~h}$ at $37^{\circ} \mathrm{C}$. The reaction was then stopped with $6 \mathrm{ml} 0.03 \mathrm{M} \mathrm{BaBr}_{2}$ in $90 \%(\mathrm{v} / \mathrm{v})$ ethanol, and the phosphorylated product was allowed to precipitate for $20 \mathrm{~min}$ at $4{ }^{\circ} \mathrm{C}$. It was then filtered through a $0.45 \mu \mathrm{m}$ Millipore membrane and rinsed twice with $80 \%(\mathrm{v} / \mathrm{v})$ cold ethanol $(2 \times 1.0 \mathrm{ml})$. The filter was placed in a vial containing $5.0 \mathrm{ml}$ Scintiverse $\mathrm{E}$ (Fisher Scientific) and the radioactivity was counted using a Beckman LS 7500 liquid scintillation system. The activities were corrected with respect to a control consisting of the same incubation medium described above but without $\mathrm{HPr}$. 
Electron microscopy. Single drops of bacterial suspension were placed on Formvar-coated grids. After $1 \mathrm{~min}$, the grids were placed on drops of $1 \%(\mathrm{w} / \mathrm{v})$ egg albumin for $5 \mathrm{~min}$ and then in a suitable dilution of rabbit anti-S. salivarius serum for $30 \mathrm{~min}$. They were then washed in distilled water and placed on drops of colloidal gold particles $(10 \mathrm{~nm})$ conjugated to goat anti-rabbit immunoglobulin $G$ (Sigma) for $30 \mathrm{~min}$. After a final wash in distilled water, they were stained with $0 \cdot 2 \%(\mathrm{w} / \mathrm{v})$ phosphotungstate $(\mathrm{pH} 7 \cdot 0)$, and examined with a Philips 201 electron microscope at an accelerating voltage of $60 \mathrm{kV}$. Bacterial cells were also fixed for $2 \mathrm{~h}$ at room temperature in cacodylate buffer $(0 \cdot 1 \mathrm{M}, \mathrm{pH} 7 \cdot 2)$ containing $1 \%(\mathrm{v} / \mathrm{v})$ glutaraldehyde and $2 \%$ $(\mathrm{v} / \mathrm{v})$ paraformaldehyde, then dehydrated in ethanol and embedded in Lowicryl K4M at $-20^{\circ} \mathrm{C}$. Polymerization was carried out in a UVC1 cryochamber (Ted Pella Inc.) with a $360 \mathrm{~nm}$ lamp at $-35^{\circ} \mathrm{C}$ for $48 \mathrm{~h}$, and then at room temperature for a further $4 \mathrm{~d}$. Thin sections were labelled as described above, and then stained with uranyl acetate and lead citrate.

\section{RESULTS}

\section{Electrophoretic analysis of proteins extracted from $S$. suis}

Cell surface components of $S$. suis were extracted by cell homogenization with a Sorvall Omnimixer. Analysis by urea-SDS-PAGE of the proteins present in the blended preparation after centrifugation revealed a major protein with a molecular mass of approximately $9 \mathrm{kDa}$ (Fig. 1, lane 2 ). To determine whether the blending step could result in cell lysis, a viable count on blood agar plates was performed prior to and after blending. The results $\left(6.6 \times 10^{7}\right.$ c.f.u. $\mathrm{ml}^{-1}$ prior to and $5 \cdot 6 \times 10^{7}$ c.f.u. $\mathrm{ml}^{-1}$ after blending) suggested that viability was not substantially affected by this treatment. Examination of the cells by light microscopy revealed that these cocci occurred singly or in pairs and that their structural integrity was preserved following blending (not shown). It was therefore unlikely that the high amount of $9 \mathrm{kDa}$

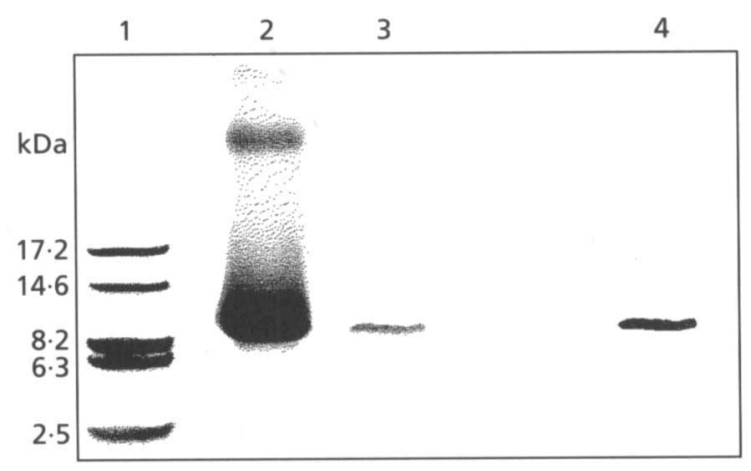

Fig. 1. Computer-assisted reproduction of SDS-urea PAGE. The gels were scanned using Deskscan II from Microsoft and the background was reduced using the software Photofinish. Lanes 1,2 and 3 represent protein bands separated by SDS-PAGE and stained with Coomassie blue; lane 4 illustrates results from a Western blot experiment. Lane 1, molecular mass markers; lane 2 , blended preparation obtained from $S$. suis 170B; lane 3 , purified $9 \mathrm{kDa}$ protein; lane 4 , immunoblot of the purified $9 \mathrm{kDa}$ S. suis protein using a rabbit anti-S. salivarius $\mathrm{HPr}$ antiserum.
Smu MASKDFHIVA ETGIHARPAT LLVQTASKFA SDITLDYKGK 40 SSa MASKDFHIVA ETGIHARPAT LLVQTASKFA SDITLDYKGK SSU ASKDFHIVA ETGIHARPAT LLVQTASKFA SDITLNYK

Fig. 2. Amino acid sequence alignments of HPr proteins from $S$. mutans (Smu) and S. salivarius (Ssa) with the first 37 amino acids determined for the $9 \mathrm{kDa}$ protein extracted from the cell surface of S. suis $170 \mathrm{~B}$ (Ssu).

protein found in the blended preparation was a consequence of an enrichment caused by cell lysis during blending. This protein was further purified to homogeneity by treatment of the blended preparation with $6 \mathrm{M}$ urea and filtration as described in Methods (Fig. 1, lane 3).

\section{Characterization of the $9 \mathrm{kDa}$ protein}

A database search using the sequence of the first 37 amino acids determined for the protein extracted from $S$. suis revealed $95 \%$ identity with the $\mathrm{N}$-terminal amino acid sequences of HPr proteins from $S$. salivarius (Gagnon et al., 1993) and S. mutans (Boyd et al., 1994) (Fig. 2). Apart from the lack of the N-terminal Met, the only difference observed between the $S$. suis protein and these streptococcal HPrs was the replacement of an aspartate at position 36 by an asparagine. The $S$. suis protein possessed the signature sequence required for the PEP-dependent phosphorylation of Gram-positive HPrs on histidine at position 15 (GIH ${ }^{15}$ ARPAT) (Reizer et al., 1993a).

The size and the N-terminal amino acid sequence of the protein isolated from the cell surface of S. suis $170 \mathrm{~B}$ suggested that this protein might be an HPr. The identity of the protein was confirmed by three series of experiments demonstrating: (1) the reactivity of the protein with a polyclonal monospecific anti-HPr antibody; (2) the capacity to be phosphorylated at the expense of PEP and ATP, a characteristic trait of HPrs from Gram-positive bacteria (Reizer et al., 1993b); and (3) its phosphocarrier activity in an in vitro PTS assay.

Western blotting demonstrated that the purified $9 \mathrm{kDa}$ protein cross-reacted with an $S$. salivarius anti-HPr antiserum (Fig. 1, lane 4), indicating a structural relationship between the $S$. suis protein and the $S$. salivarius HPr. The cross-reactivity of the $9 \mathrm{kDa}$ protein with an anti-HPr antiserum allowed us to demonstrate by crossed immunoelectrophoresis that the protein could be phosphorylated by PEP and ATP. We had already shown that this technique allows a clear separation of free $\mathrm{HPr}$ and $\mathrm{HPr}$ $\mathrm{P}$ (Vadeboncoeur et al., 1991a). HPr(His-P), produced by EI and $\mathrm{PEP}$, and $\mathrm{HPr}($ Ser-P), produced by a membraneassociated kinase and ATP, migrate to the same position. However, the heat stability of the different phosphate bonds provides a convenient way to identify these derivatives. The phosphoamidate bond $[\mathrm{HPr}(\mathrm{His}-\mathrm{P})]$ is thermolabile, whereas the phosphomonoester bond $[\mathrm{HPr}($ Ser-P)] is thermostable (Martensen, 1984). The $S$. suis protein was first incubated in the presence of purified EI and PEP. After the incubation period, a portion of the sample was boiled for $3 \mathrm{~min}$ before examination by 
(a)
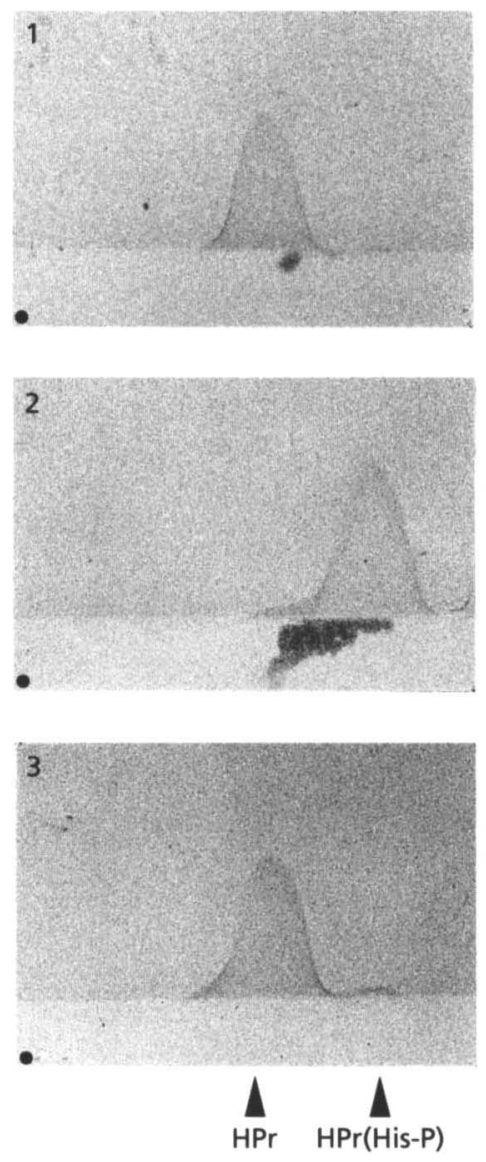

(b)
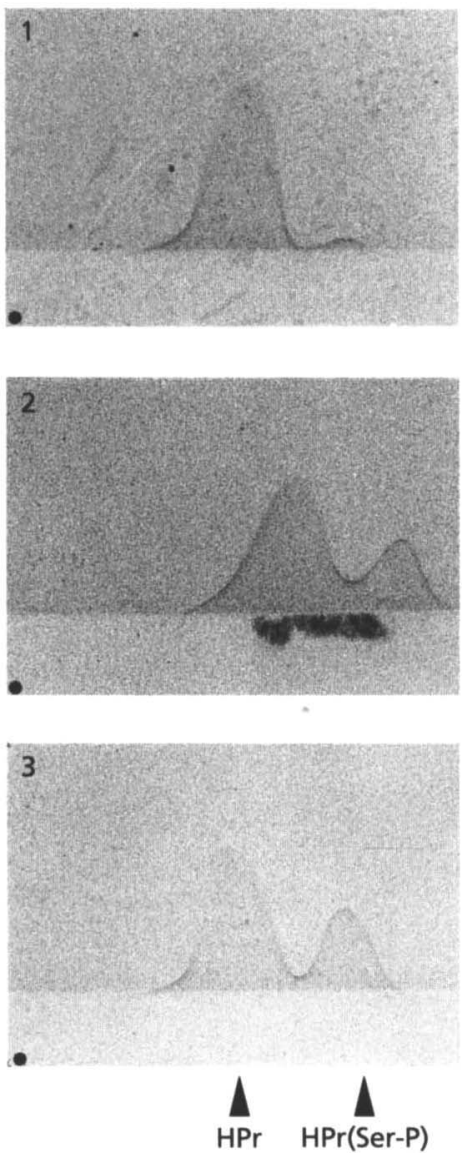

Fig. 3. Crossed immunoelectrophoresis analysis of in vitro phosphorylation assays with the $9 \mathrm{kDa}$ protein extracted from $S$. suis. (a) 1, protein purified from S. suis; $2, S$. suis protein after incubation for $60 \mathrm{~min}$ at room temperature with $2 \mathrm{mM}$ PEP and $37.5 \mathrm{ng} \mathrm{El}$ purified from S. sanguis; 3, same as 2, but boiled for $3 \mathrm{~min}$ before electrophoresis. (b) $1,0.5 \mathrm{mg}$ of the protein extracted from $S$. suis; $2, S$. suis protein after incubation for $90 \mathrm{~min}$ at $37^{\circ} \mathrm{C}$ in the presence of $2.3 \mu \mathrm{g}$ of membrane proteins isolated from $S$. salivarius as a source of $\mathrm{HPr}$ kinase and $0.1 \mathrm{mM}$ ATP; 3 , same as 2, but boiled for $3 \mathrm{~min}$ before electrophoresis. Samples were probed with a rabbit anti-S. salivarius HPr antiserum (12 mg total serum proteins). crossed immunoelectrophoresis. The results in Fig. 3(a) indicate that exposure of the $S$. suis protein to EI in the presence of PEP gives rise to a heat-labile phosphoprotein that cross-reacts with an anti-HPr antibody. The protein was also incubated with ATP and S. salivarius membrane fragments as a source of HPr kinase. Crossed immunoelectrophoresis of heated and unheated samples following incubation with ATP revealed that the $S$. suis protein could be phosphorylated at the expense of ATP to produce a thermostable phosphoprotein (Fig. 3b). Lsing purified S. salivarius $\mathrm{HPr}$, we showed that the phosphorylated and free forms of the $S$. suis protein migrated in crossed immunoelectrophoresis as phospho- and free $S$. salivarius $\mathrm{HPr}$ (not shown).

Finally, we showed that the $9 \mathrm{kDa}$ protein extracted from S. suis $170 \mathrm{~B}$ was able to catalyse the PEP-dependent phosphorylation of a P'TS sugar (fructose) in the presence of purified EI and membrane fragments isolated from fructose-grown cells of $S$. salivarius as a source of $\mathrm{II}^{\mathrm{Fru}}$. The activity obtained with the $S$. suis protein was, however, approximately fourfold lower than that obtained with purified S. salivarius $\operatorname{HPr}[259 \pm 24$ vs $1118 \pm 145 \mathrm{nmol}$ phosphorylated fructose $(\mathrm{mg} \mathrm{HPr})^{-1}$ $\mathrm{h}^{-1}$ ]. The fact that the $S$. suis protein was exposed to urea during its purification might explain this lower specific activity.

\section{Location of the $9 \mathrm{kDa}$ protein}

The ultrastructural location of the $9 \mathrm{kDa}$ protein was determined by immunogold electron microscopy using $S$. salivarius $\mathrm{HPr}$ antiserum. Experiments performed with whole cells showed that the protein was associated with material surrounding the cells (Fig. 4a). No labelling was detected with a pre-immune serum (Fig. 4b). Experiments with thin sections showed that the anti-HPr antibody preparation reacted with a protein that was distributed throughout the cytoplasm, with a significant proportion of the HPr located at the cell periphery (Fig. 4c). Western blot experiments carried out with crude as well as with membrane-free cellular extracts confirmed that the antibody reacted solely with a protein that migrated to the same position as HPr in SDS-PAGE (not shown; see also results below).

\section{S. suis contains two forms of $\mathrm{HPr}$}

That $S$. suis contains the two forms of HPr previously reported in streptococci and lactococci (Robitaille et al., 1991) was demonstrated by separating the cytoplasmic proteins of $S$. suis and $S$. salivarius by non-denaturing electrophoresis, transferring the proteins to a nitrocellulose membrane, and testing for the presence of $\mathrm{HPr}$ with an antibody directed against the $S$. salivarius $\mathrm{HPr}$. 


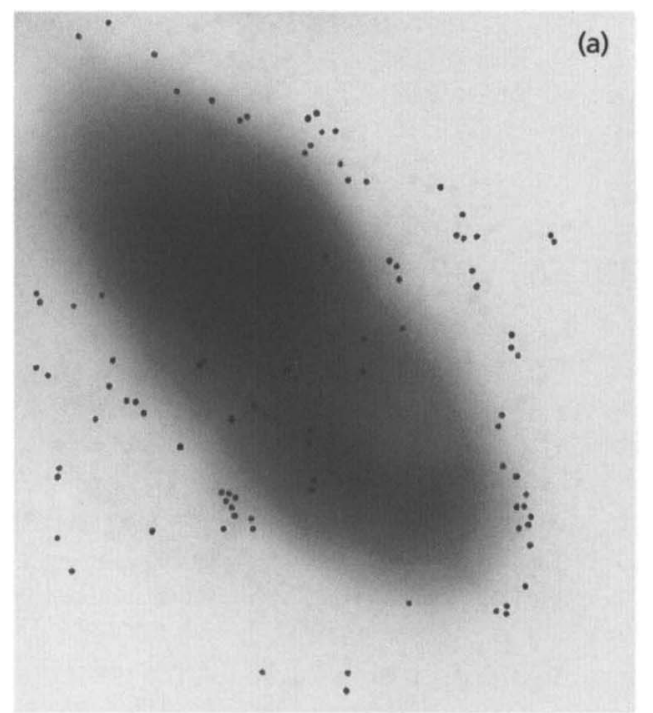

(b)
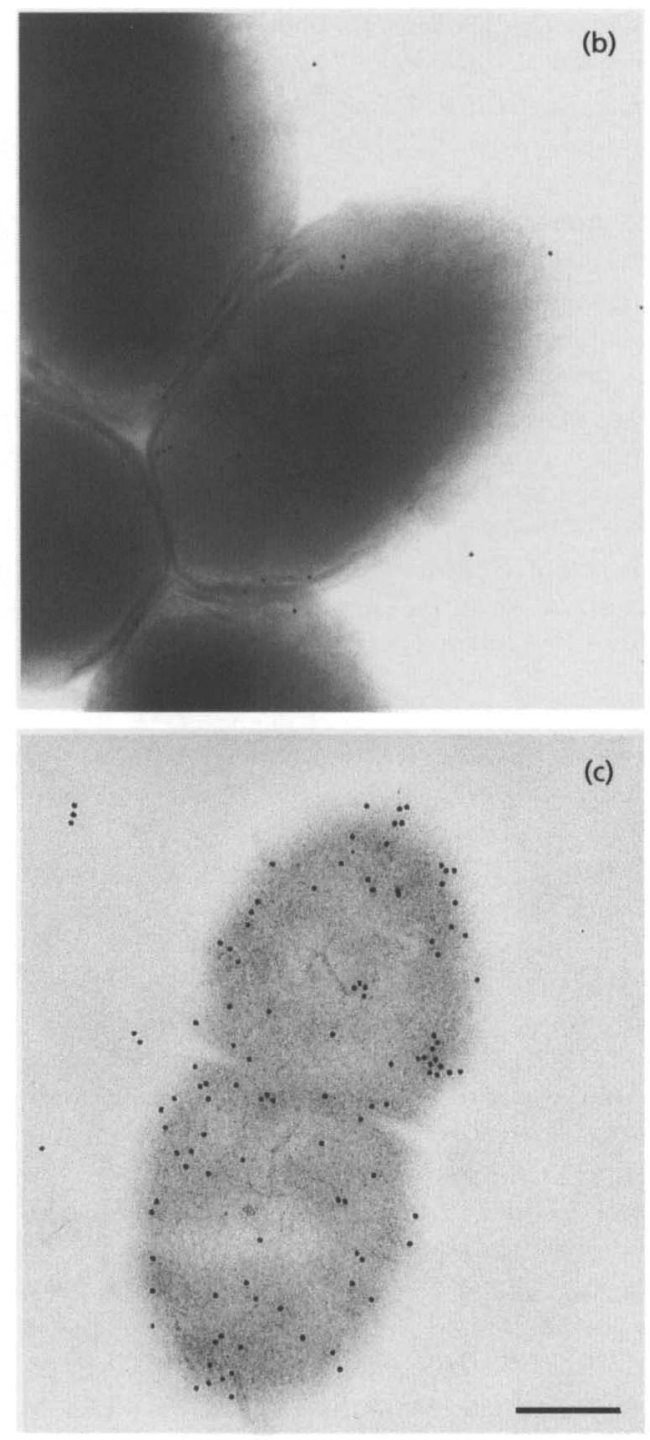

Fig. 4. Transmission electron micrographs of $S$. suis $170 \mathrm{~B}$. (a) Whole cells incubated sequentially with anti-HPr antibody and gold conjugate; (b) whole cells treated as in (a) but with preimmune serum; (c) thin section treated as in (a). Bar, $200 \mathrm{~nm}$.

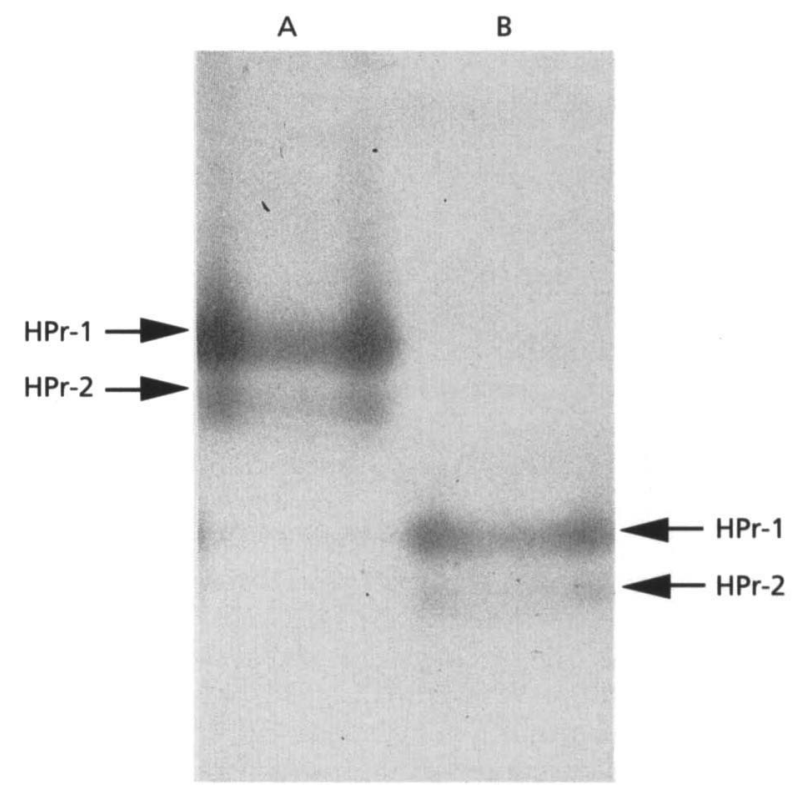

Fig. 5. Western analysis with anti-HPr antibody. Membrane-free cell extracts containing $10 \mu \mathrm{g}$ protein were separated electrophoretically under non-denaturing conditions, electrophoretically transferred to a nitrocellulose membrane and revealed with $\mathrm{HPr}$ antibody. Lane $A, S$. suis; lane $B, S$. salivarius.

The results shown in Fig. 5 indicate that S. suis (Fig. 5, lane A) and S. salivarius (Fig. 5, lane B) possess two proteins that react with the anti-HPr antibody, the slowmigrating form of the doublet corresponding to HPr-1 (HPr lacking the $\mathrm{N}$-terminal Met) and the fast-migrating form corresponding to HPr-2 (HPr possessing the Nterminal Met) (Vadeboncoeur et al., 1991b). The S. suis HPr migrated more slowly than the $S$. salivarius protein, indicating differences in the conformation and/or the amino acid composition of the two proteins. This is consistent with the observation that the aspartate at position 36 is replaced by an asparagine in the $S$. suis $\mathrm{HPr}$ (Fig. 2). The results in Fig. 5 also indicate that the anti-S. salivarius $\mathrm{HPr}$ antiserum did not react with any cytoplasmic protein other than HPr-1 and HPr-2.

\section{DISCUSSION}

The presence of a PTS has never been reported in S. suis. The presence in this species of two PTS proteins, $\mathrm{HPr}$

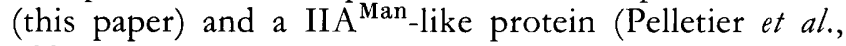
1995), suggests that $S$. suis possesses a functional PTS, which is consistent with reports that this transport system is commonly found in fermentative eubacteria (Dills et al., 1980).

There is little doubt that the protein extracted from whole cells of $S$. suis was actually $\mathrm{HPr}$. The evidence is as follows: (i) the $S$. suis protein showed homology over the first $35 \mathrm{~N}$-terminal amino acid residues with the HPrs of $S$. salivarius and $S$. mutans, including the signature sequence for the site of PEP-dependent phosphorylation; (ii) it 
cross-reacted with the $S$. salivarius polyclonal monospecific anti-HPr antiserum; (iii) it could be phosphorylated by EI at the expense of PEP, and by a membrane-associated kinase at the expense of ATP; and (iv) it possessed phosphocarrier activity when used as a source of HPr in an in vitro PTS assay.

HPr is usually found in the cytoplasm or associated with the inner surface of the cytoplasmic membrane (Saier et al., 1982). Results of three independent studies, however, suggest that streptococcal HPr might be associated with the cell surface. Jenkinson (1989) reported the purification of $\mathrm{HPr}$ from $S$. sanguis using an extraction procedure designed to remove cell-surface proteins. Sutcliffe et al. (1993) demonstrated that a surface antigen of S. mutans, designated antigen $\mathrm{D}$, is an $\mathrm{HPr}$, and showed that it could be extracted from whole cells by HECAMEG and lauroyl sarcosinate, two detergents used to extract surface components (Russell, 1988). Finally, Gerlach et al. (1992) reported the purification of $\mathrm{HPr}$ from culture supernatants of $S$. pyogenes. Results reported in this paper, for the first time, provide convincing direct evidence that a portion of the cellular $\mathrm{HPr}$ is located at the cell surface in streptococci. This is suggested by the fact that the $S$. suis $\mathrm{HPr}$ is preferentially extracted following blending of the cells, a method used to extract cell surface appendages (Heckels \& Virji, 1988) without causing significant lysis. The presence of HPr on the cell surface was confirmed by immunogold electron microscopy carried out with whole cells, demonstrating the association of $\mathrm{HPr}$ with material surrounding the cell.

We have previously shown that several streptococcal species, including $S$. salivarius, $S$. thermophilus, $S$. mutans, $S$. sobrinus, $S$. rattus, $S$. sanguis and $S$. bovis, which belong to four different phylogenetic clusters (Bentley et al., 1991), possess two forms of $\mathrm{HPr}$ that can be distinguished by the absence (HPr-1) or the presence ( $\mathrm{HPr}-2)$ of the N-terminal Met (Robitaille et al., 1991; Vadeboncoeur et al., 1991b). We have demonstrated in this study that this dimorphism also occurs in S. suis, a species that is phylogenetically separate from other streptococcal species (Bentley et al., 1991), suggesting that this phenomenon is ubiquitous among the genus Streptococcus. Although both forms of $\mathrm{HPr}$ are found in crude cell extracts of streptococcal cells, only $\mathrm{HPr}-1$ has been found associated with the external cell surface (this paper; Gerlach et al., 1992; Jenkinson, 1989; Sutcliffe et al., 1993). Whether there is a cause-effect relationship between the conditional removal of the $\mathrm{N}$ terminal Met of HPr and its cellular location remains to be determined. Further research is also needed to unravel the function of extracellular HPr and to define the molecular mechanism of its surface localization. This latter aspect is particularly intriguing as the HPr protein has no sequence corresponding to previously described signal peptides (Simonen \& Palva, 1993).

\section{ACKNOWLEDGEMENTS}

This research was supported by the Medical Research Council of Canada, operating grant no. MT-6979 to C. Vadeboncoeur, and by CORPAQ no. 3503 to J. Daniel Dubreuil. M. Frenette is a scholar of the Fonds de la Recherche en Santé du Québec. We are grateful to France Dumas for the amino acid sequence analysis and to Bernadette Foiry for the electron microscopy work. We also appreciate the editorial assistance of Gene Bourgeau.

\section{REFERENCES}

Arends, J. P. \& Zanen, H. C. (1988). Meningitis caused by Streptococcus suis in humans. Rev Infect Dis 10, 131-137.

Bentley, R. W., Leigh, J. A. \& Collins, M. D. (1991). Intragenic structure of Streptococcus based on comparative analysis of smallsubunit $r$ RNA sequences. Int J Syst Bacteriol 41, 487-494.

Boyd, D. A., Cvitkovitch, D. G. \& Hamilton, I. R. (1994). Sequence and expression of the genes for $\mathrm{HPr}(p t s H)$ and enzyme I $(p t s I)$ of the phosphoenolpyruvate-dependent phosphotransferase transport system from Streptococcus mutans. Infect Immun 62, 1156-1165.

Deutscher, J., Sossna, G. \& Gonzy-Treboul, G. (1989). Regulatory functions of the phosphocarrier protein HPr of the phosphoenolpyruvate-dependent phosphotransferase system in Grampositive bacteria. FEMS Microbiol Lett 63, 67-174.

Devereux, J., Haeberli, P. \& Smithies, O. (1984). A comprehensive set of sequence analysis programs for the VAX. Nucleic Acids Res 12, 387-395.

Dills, S. S., Apperson, A., Schmidt, M. \& Saier, M. H., Jr (1980). Carbohydrate transport in bacteria. Microbiol Rev 44, 385-418.

Gagnon, G., Vadeboncoeur, C. \& Frenette, M. (1993). Phosphotransferase system of Streptococcus salivarius: characterization of the ptsH gene and its product. Gene 136, 27-34.

Gauthier, L., Mayrand, D. \& Vadeboncoeur, C. (1984). Isolation of a novel protein involved in the transport of fructose by an inducible phosphoenolpyruvate fructose phosphotransferase system in Streptococcus mutans. J Bacteriol 160, 755-763.

Gerlach, D., Alouf, H., Moraved, L., Pavlik, M. \& Kohler, W. (1992). The characterization of two new low molecular weight proteins (LMPs) from Streptococcus pyogenes. Zentralbl Bakteriol Mikrobiol Hyg 277, 1-9.

Hamilton, I. R. (1987). Effect of changing environment on sugar transport and metabolism by oral bacteria. In Sugar Transport and Metabolism by Gram-positive Bacteria, pp. 94-133. Edited by J. Reizer \& A. Peterkofsky. Chichester: Ellis Horwood.

Hamilton, I. R., Gauthier, L., Desjardins, B. \& Vadeboncoeur, C. (1989). Concentration-dependent repression of the soluble and membrane components of the Streptococcus mutans phosphoenolpyruvate: sugar phosphotransferase system by glucose. $J$ Bacteriol 171, 2942-2948.

Hawkes, R. (1982). Identification of concavalin A-binding proteins after sodium dodecyl sulfate-gel electrophoresis and protein blotting. Anal Biochem 123, 143-146.

Heckels, J. E. \& Virji, M. (1988). Separation and purification of surface components. In Bacterial Cell Surface Techniques, pp. 67-135. Edited by I. C. Hancock \& I. R. Poxton. Chichester: John Wiley.

Hewick, R. M., Humkapiller, M. W., Hood, L. E. \& Dreyer, W. J. (1980). A gas-liquid solid phase peptide and protein sequenator. $J$ Biol Chem 256, 7990-7997.

Higgins, R., Gottschalk, M., Mittal, K. R. \& Beaudoin, M. (1990). Streptococcus suis infections in swine. A 16 month study. Can J Vet Res 54, 170-173.

Hommez, J., Devriese, L. A., Henrichsen, J. \& Castryck, F. (1986). Identification and characterization of Streptococcus suis. Vet Microbiol 11, 349-355. 
Jenkinson, H. F. (1989). Properties of a phosphocarrier protein $(\mathrm{HPr})$ extracted from intact cells of Streptococcus sanguis. J Gen Microbiol 135, 3183-3197.

Martensen, T. M. (1984). Chemical properties, isolation and analysis of O-phosphates in proteins. Methods Enzymol 107, 3-23.

Meadow, N. D., Fox, D. K. \& Roseman, S. (1990). The bacterial phosphoenolpyruvate:glycose phosphotransferase system. Annu Rev Biocbem 5, 497-542.

Pelletier, M., Frenette, M. \& Vadeboncoeur, C. (1995). Distribution of proteins similar to $\mathrm{III}_{\mathrm{H}}^{\text {Man }}$ and $\mathrm{III}_{\mathbf{L}}^{\text {Man }}$ of the Streptococcus salivarius phosphoenolpyruvate: mannose-glucose phosphotransferase system among oral and nonoral bacteria. J Bacteriol 177, 2270-2275.

Postma, P. W., Lengeler, J.W. \& Jacobson, G. (1993). Phosphoenolpyruvate:carbohydrate phosphotransferase systems of bacteria. Microbiol Rev 57, 543-594.

Reizer, J., Deutscher, J. \& Saier, M. H., Jr (1989). Metabolitesensitive, ATP-dependent, protein kinase-catalysed phosphorylation of HPr, a phosphocarrier protein of the phosphotransferase system in Gram-positive bacteria. Biochimie 71, 989-996.

Reizer, J., Hoischen, C., Reizer, A., Pham, T. N. \& Saier, M. H., Jr (1993a). Sequence analyses and evolutionary relationships among the energy-coupling proteins Enzyme I and HPr of the bacterial phosphoenolpyruvate: sugar phosphotranferase system. Protein $S_{c i}$ 2, 506-521.

Reizer, J, Romano, A. H. \& Deutscher, J. (1993b). The role of phosphorylation of HPr, a phosphocarrier protein of the phosphotransferase system, in the regulation of carbon metabolism in Gram-positive bacteria. J Cell Biochem 51, 19-24.

Robitaille, D., Gauthier, L. \& Vadeboncoeur, C. (1991). The presence of two forms of the phosphocarrier protein HPr of the phosphoenolpyruvate:sugar phosphotransferase system in streptococci. Biochimie 73, 573-581.

Russell, R. R. B. (1988). Isolation and purification of proteins linked to the cell wall in Gram-positive bacteria. . In Bacterial Cell Surface Tecbniques, pp. 104-110. Edited by I. C. Hancock \& I. R. Poxton. Chichester: John Wiley.

Saier, M. H., Jr \& Reizer, J. (1992). Proposed uniform nomenclature for the proteins and protein domains of the bacterial phosphoenolpyruvate: sugar phosphotransferase system. J Bacteriol 174, 1433-1438.

Saier, M. H., Jr, Cox, D. F., Feucht, B. U. \& Novotny, M. J. (1982). Evidence for the functional association of Enzyme I and HPr of the phosphoenolpyruvate-sugar phosphotranferase system with the membrane in sealed vesicles of Escherichia coli. J Cell Biochem 18, 231-238.

Simonen, M. \& Palva, I. (1993). Protein secretion in Bacillus species. Microbiol Rev 57, 109-137.

Sutcliffe, I. C., Hogg, S. D. \& Russell, R. R. B. (1993). Identification of Streptococcus mutans antigen D as the HPr protein of the sugarphosphotransferase transport system. FEMS Microbiol Lett 107, 67-70.

Swank, R. T. \& Munkres, K. D. (1971). Molecular weight analysis of oligopeptides by electrophoresis in polyacrylamide gel with sodium dodecylsulfate. Anal Biochem 39, 462- 477.

Thompson, J. (1987). Sugar transport in the lactic acid bacteria. In Sugar Transport and Metabolism by Gram-positive Bacteria, pp. 13-38. Edited by J. Reizer \& A. Peterkofsky. Chichester: Ellis Horwood.

Towbin, H., Staehelin, T. \& Gordon, J. (1979). Electrophoretic transfer of proteins from polyacrylamide gels to nitrocellulose sheets: procedure and some applications. Proc Natl Acad Sci US A 76, 4350-4354.

Trottier, S., Higgins, R., Brochu, G. \& Gottschalk, M. (1991). A case of human endocarditis due to Streptococcus suis in North America. Rev Infect Dis 13, 1251-1252.

Vadeboncoeur, C. (1995). HPr: Heteromorphous Protein. Res Microbiol 146, 525-530.

Vadeboncoeur, C., Brochu, D. \& Reizer, J. (1991a). Quantitative determination of the intracellular concentration of the various forms of $\mathrm{HPr}$, a phosphocarrier protein of the phosphoenolpyruvate: sugar phosphotransferase system in growing cells of oral streptococci. Anal Biochem 196, 24-30.

Vadeboncoeur, C., Konishi, Y., Dumas, F., Gauthier, L. \& Frenette, M. (1991b). HPr polymorphism in oral streptococci is caused by the partial removal of the $\mathrm{N}$-terminal methionine. Biochimie 73, 1427-1430.

Vadeboncoeur, C., Brochu, D., Trahan, L., Fradette, J. \& Gingras, S. (1993). Amino-terminal methionine processing of the protein $\mathrm{HPr}$ in Streptococcus salivarius grown in continuous culture. FEMS Microbiol Lett 111, 197-202.

Received 9 October 1995; revised 15 November 1995; accepted 28 November 1995. 